\title{
Quantifying the Effects of Lance Nematode Parasitism in Creeping Bentgrass
}

\author{
D. M. Settle, Chicago District Golf Association, Lemont, IL 60439; J. D. Fry, Department of Horticulture and Rec- \\ reation Resources, and G. A. Milliken, Department of Statistics, Kansas State University, Manhattan 66506; \\ N. A. Tisserat, Department of Bioagricultural Sciences and Pest Management, Colorado State University, Fort \\ Collins 80523; and T. C. Todd, Department of Plant Pathology, Kansas State University, Manhattan
}

\begin{abstract}
Settle, D. M., Fry, J. D., Milliken, G. A., Tisserat, N. A., and Todd, T. C. 2007. Quantifying the effects of lance nematode parasitism in creeping bentgrass. Plant Dis. 91:1170-1179.

We compared photosynthesis and multispectral radiometry (MSR) measurements with visual quality ratings for assessment of feeding injury to creeping bentgrass caused by the lance nematode (Hoplolaimus galeatus) using artificially infested microplots and a naturally infested putting green. Nematode feeding resulted in negative visual and MSR effects on creeping bentgrass in microplots. Visual quality ratings were correlated more consistently with nematode densities than either individual MSR variables or factor models of MSR variables. Threshold estimates for $H$. galeatus population densities associated with unacceptable bentgrass quality in microplots varied widely by month and year. Similarly, the relationship between $H$. galeatus population density and turf health indicators (including MSR measurements, visual ratings, and net photosynthetic rate) varied with cultivar and management practice (irrigation frequency and mowing height) in the naturally infested putting green. Notably, negative effects of nematode feeding were not consistently associated with more stressful management practices, suggesting that stress avoidance is not a reliable deterrent to $H$. galeatus damage in creeping bentgrass. Damage thresholds for this nematode-host association are dynamic and should be used with caution.
\end{abstract}

Additional keywords: Agrostis palustris, reflectance, turfgrass

Creeping bentgrass (Agrostis palustris Huds.) is widely used on golf course putting greens because of its fine texture and ability to withstand low mowing heights (13). However, creeping bentgrass quality can be adversely affected by root and foliar fungal diseases $(12,46)$, as well as by environmental and site-specific sources of midsummer stress, including high air or soil temperatures $(19,20,58-60)$ and restricted airflow (24). Additionally, phytoparasitic nematodes frequently are associated with the roots of sand-based creeping bentgrass putting greens $(5,7,49,51,56)$, although their impact on turf quality, especially during periods of midsummer stress, has been difficult to demonstrate. Lukens and Miller (31) reported that a combination of lance (Hoplolaimus sp.) and stunt (Tylenchorhynchus dubius (Butschli) Filipjev) nematodes caused foliar chlorosis and stunted growth of Penncross creeping bentgrass in the greenhouse. Todd and Tisserat (52) observed that foliar discoloration of a creeping bentgrass putting green increased linearly with logarithmic Hop-

Corresponding author: N. A. Tisserat

E-mail: Ned.Tisserat@ colostate.edu

Accepted for publication 10 April 2007.

doi:10.1094/PDIS-91-9-1170

(C) 2007 The American Phytopathological Society lolaimus galeatus (Cobb) Thorne population increases, but in only 1 of 3 years of the study. They speculated that relatively high populations of $H$. galeatus were necessary to cause foliar symptoms and that nematode population thresholds necessary to cause turf damage could vary depending on environmental factors. Several other studies have shown minimal effects of phytoparasitic nematodes on creeping bentgrass quality $(6,25,36,55)$. Traditional measurements have failed to consistently detect or describe the effects of nematode parasitism on creeping bentgrass under both field and greenhouse conditions. Therefore, comparison of multiple bentgrass health indicators, including visual and physiological assessments, may shed new light on the best method or methods to quantify these relationships.

Quantifying the effects of nematode root feeding on creeping bentgrass health has been limited primarily to visual quality ratings. Visual quality is a common system that a majority of turfgrass scientists use. It summarizes multiple canopy characteristics, including color, density, uniformity, and texture. Visual quality ratings have inherent shortcomings. They lack a universal scale, are subjective, and require training and practice. Each of the four characteristics that comprise visual quality can be weighted differently by an individual; therefore, the main contributing factor of plant health decline across investigations is difficult to assess.

A nondestructive alternative in assessing plant health is ground-based narrow-band multispectral radiometry (MSR), $(21,38,57)$. MSR measures discrete wavelengths of solar radiation that is intercepted and reflected from the plant canopy, and can be more accurate than visual ratings when determining disease severity (17,39-41). Reflectance of the red wavelength $(661 \mathrm{~nm})$ can estimate foliar chlorophyll content, farred $(690$ to $760 \mathrm{~nm})$ can indicate leaf stress, and near-infrared $(810 \mathrm{~nm})$ is associated with plant cellular changes, including moisture deficits $(2,4,35,53)$. MSR in the nearinfrared wavelength has been used successfully to assess damage to creeping bentgrass resulting from dollar spot (caused by Sclerotinia homoeocarpa $\mathrm{F}$. T. Bennett) $(39,43)$ and brown patch (caused by Rhizoctonia solani Kühn) $(42,43)$. MSR also has been used to detect nematode injury in cotton (Gossypium hirsutum L.) (14) and soybean (Glycine max (L.) Merr) (40).

Portable infrared gas analyzers can estimate plant photosynthetic rates (11), indicate creeping bentgrass health (28), and may be able to detect nematode rootfeeding effects to creeping bentgrass. Photosynthetic reductions resulting from nematode feeding have been reported in cotton (37), potato (Solanarum tuberosum L.) $(15,44)$ soybean $(23)$, grape (Vitis vinifera L.) (32,33), yellow wax bean (Phaseolus vulgaris L.) (34), bean (Vicia fabia L.) (30), and tomato (Lycopersicon sp.) (29).

Interactions between nematodes and management practices on creeping bentgrass health have not been studied in detail, although soil physical properties and nitrogen fertilization have been shown to influence nematode populations. Walker et al. (54) reported that populations of Hoplolaimus and Criconemella spp. in Oklahoma sand-based putting greens increased as the percent of sand fraction between 106 and $250 \mu \mathrm{m}$ in diameter increased. There was a negative relationship between soil bulk density and total parasitic nematode populations, but nematode densities increased with soil measures of $\mathrm{NO}_{3}-\mathrm{N}$, plant-available $\mathrm{K}$, and organic matter. Davis and Dernoeden (6) reported that activated sewage sludge and poultry waste material increased lance nematode populations after 2 years when compared with several other organic nitrogen sources. 
Our objective was to better describe the relationship between $H$. galeatus population densities and bentgrass health using both visual and MSR indices and measurements of net photosynthetic rate $\left(P_{n}\right)$. We also examined the influence of cultivar, clipping height, and irrigation frequency in association with $H$. galeatus populations on bentgrass quality on a naturally infested putting green. Population responses of $H$. galeatus to these experimental manipulations were reported separately (47). Briefly, H. galeatus population densities were spatially and temporally variable, but no consistent trends in the effects of turfgrass management practices were detected. Peak population densities occurred in late summer or early autumn and often coincided with periods of maximum turfgrass stress from environmental factors (e.g., temperature). Nematode numbers during these months consistently exceeded estimated threshold levels (52).

\section{MATERIALS AND METHODS}

Experiment design. Microplots. Twenty microplots were established in April 2000 on a sand-based putting green at the Rocky Ford Turfgrass Research Center, Manhattan, KS. The green, which was seeded to A-4 creeping bentgrass at 49 $\mathrm{kg} / \mathrm{ha}$ in fall 1998, had a root zone of $97.5 \%$ sand and $2.5 \%$ clay and a $\mathrm{pH}$ of 7.5 . Microplots were spaced $1 \mathrm{~m}$ apart in a 4by-5-m area. Each microplot consisted of a 30.5-cm-diameter schedule 40 polyvinylchloride (PVC) tube (Diamond Plastics Corp, Grand Island, NE) placed into the green to a depth of $38 \mathrm{~cm}$. The construction of these microplots was previously described by Settle et al. (47).

$H$. galeatus inoculum was extracted from 380 liters of naturally infested soil collected from a bentgrass putting green at the same location using a modified sucrose flotation technique (22). Other phytoparasitic nematodes were present at low populations, but were not detected in the final inoculum following extraction. On 6 June 2000, microplots were inoculated with nematode-free filtrate (control) or infested with one of three $H$. galeatus (adults + juveniles) population densities as previously described by Settle et al. (47). Treatments were arranged in a completely randomized block design with five replications.

The creeping bentgrass putting green containing the microplot study was clipped at a 4.0 -mm height 6 days per week. The green was maintained using best management practices for irrigation, fertility, and fungal disease management as previously detailed by Settle et al. (47). Periodic sand top-dressing was used to compensate for soil settling in the microplots, which was greatest during the first year. Insecticides were not used during the study.

Putting green. The effects of turfgrass management practices on nematode dam- age were investigated using a second putting green constructed to USGA specifications at the Rocky Ford Turfgrass Research Center. The study area consisted of an 8by-24-m area with four creeping bentgrass cultivars which received clipping height and irrigation treatments. The root zone mixture had a sand content of $97.9 \%$, an organic matter content of $2.1 \%$, a pH of 7.3 , and a bulk density of $1.5 \mathrm{~g} \mathrm{~cm}^{-3}$. The green was naturally infested with phytoparasitic nematodes. H. galeatus populations dominated, but Criconemella, Paratrichodorus, Hemicycliophora, and Helicotylenchus spp. also were present in low populations (20 to 90 per $100 \mathrm{~g}$ of dry soil).

Treatments were arranged in a strip-strip plot design with three replications. Wholeplot strip factors consisted of 2-by-8-m cultivar strips of Crenshaw, L-93, Penncross, or Providence that were seeded in May 1996 at $49 \mathrm{~kg} \mathrm{ha}^{-1}$ and two 4-by-8-m irrigation strips arranged in a randomized complete block design. The entire green was irrigated with $1 \mathrm{~cm}$ of water at $0600 \mathrm{~h}$ three times weekly ( $3 \mathrm{~cm} /$ week) using an automated irrigation system. One of the irrigation strips received supplemental hand watering $(0.5 \mathrm{~cm} /$ day $) 6$ days per week at $1400 \mathrm{~h}$ for a total irrigation of 6.0 $\mathrm{cm} /$ week. Cultivar plots were split into two 1-by-8-m strips that were mowed at 3.2 or $4.0 \mathrm{~mm} 6$ days per week. The entire green was mowed 6 days per week to a height of $4.0 \mathrm{~mm}$ with a triplex greensmower. Plots requiring the $3.2-\mathrm{mm}$ clipping height were mowed again with a walk-behind greensmower.

Nematode extraction. H. galeatus populations in microplots were determined during the first week of each month from June to September in 2002 and 2003. Each microplot was systematically sampled monthly by collecting two soil cores, each $2 \mathrm{~cm}$ in diameter by $13.5 \mathrm{~cm}$ deep. The two cores were removed along a radius and progressing 30 degrees clockwise, such that a new area was sampled each month. Core holes were filled with sand. Nematodes were extracted from $75 \mathrm{~g}$ of bulked, mixed soil using a modified sucrose flotation technique (22). Detailed microplot extraction methods have been previously described by Settle et al. (47). Nematodes were collected in $10 \mathrm{ml}$ of water and aliquots of this suspension were used to identify and quantify all phytopathogenic nematodes under $\times 40$ or $\times 100$ magnification. Lance nematodes were enumerated by life stage. Approximately $100 \mathrm{~g}$ of the remaining soil sample was used to calculate gravimetric soil moisture content ([fresh weight - dry weight $] /$ fresh weight) and nematode population densities were standardized by weight (per $100 \mathrm{~g}$ of dry soil). Summer densities of $H$. galeatus (per $100 \mathrm{~g}$ of soil) in infested microplots varied according to year with average/maximum numbers of 679/1,352 during 2002 and
498/1,614 during 2003. During summer, maximum $H$. galeatus populations occurred in July 2002 and September 2003 (47).

Sampling protocol for the bentgrass green varied slightly from the microplots. Nematode populations were determined monthly by removing three soil cores, each $2 \mathrm{~cm}$ in diameter by $13.5 \mathrm{~cm}$ deep, from two locations in each plot in 2001 and 2002. H. galeatus populations on the putting green ranged from 0 to $>2,000$ per 100 $\mathrm{g}$ of soil, were spatially aggregated, and peaked during early August in 2001 and 2002. The average/maximum $H$. galeatus populations were $445 / 1,647$ in 2001 and $701 / 2,426$ in 2002 per $100 \mathrm{~g}$ of soil (47).

Measurements. Bentgrass quality was rated each month and during the same week in which soil samples were removed for nematode extraction. Bentgrass quality ratings were on a proportional 0-to-9 scale, where 9 represented optimal color, density, and uniformity (i.e., $100 \%$ turf quality), 6 represented a minimal acceptable putting green quality (i.e., $70 \%$ turf quality), and 0 represented brown, dead turf. Percent bentgrass coverage of the putting green surface was estimated visually.

Plant shoot density and root biomass was measured monthly from June to September 2002 and 2003 (except June and August 2002) in microplots. A 4.5-by-16$\mathrm{cm}$ plant and soil core was removed from each microplot. The top $1 \mathrm{~cm}$ was cut from the core and the total number of bentgrass shoots was counted. The remaining core was cut into two sections representing root zone depths of 1 to 6 and 6 to $16 \mathrm{~cm}$. Each core was washed carefully in running tap water over a $355-\mu \mathrm{m}$ sieve. Roots retained on the mesh were dried at $45^{\circ} \mathrm{C}$ for 1 week and weighed. Canopy chlorophyll index (CI), leaf area index (LAI), and green leaf biomass, expressed as normalized difference vegetation index (NDVI), were estimated each month within 3 days of the visual rating by placing a multispectral radiometer over the turfgrass canopy (Cropscan Inc., Rochester, MN). The multispectral radiometer, which intercepts and quantifies surface-reflected sunlight wavelengths, was calibrated at the factory prior to the beginning of each year. Percent reflectance was calculated as reflected irradiance/incoming irradiance using the Cropscan postprocessing program which applies sun angle cosine corrections to the millivolt $(\mathrm{mV})$ readings of each sensor. All radiometer measurements were taken $2 \mathrm{~m}$ above the middle of each 1-by-8-m plot or $61 \mathrm{~cm}$ above each 30.5-cm-diameter microplot. Each site was measured twice and the values were averaged. Canopy reflectance measurements only were taken $2 \mathrm{~h}$ before or after solar noon during cloudfree conditions. Creeping bentgrass canopy reflectance wavelengths of $706,760 \mathrm{~nm}=$ far red (10), and $813 \mathrm{~nm}=$ near-infrared (42) were used to sense leaf changes 
caused by stress or disease. Additionally, red reflective spectra $(647$ to $760 \mathrm{~nm})$ are known to increase regardless of plant stressor or plant species (3). MSR indices of CI, LAI, and NDVI were calculated using 661-nm (red color) or 935-nm (nearinfrared) wavelengths $(1,18,28)$, expressed as $\mathrm{CI}=1 / \mathrm{R}_{661}, \mathrm{LAI}=\mathrm{R}_{935} / \mathrm{R}_{661}$, and NDVI $=\left(\mathrm{R}_{935}-\mathrm{R}_{661}\right) /\left(\mathrm{R}_{935}+\mathrm{R}_{661}\right)$.

Turfgrass canopy net photosynthesis $\left(\mathrm{P}_{\mathrm{n}}\right)$ was measured using a 10-cm-diameter opening of a silicon-sealed transparent cubic plexiglass chamber $(15 \mathrm{~cm}$ long by $15 \mathrm{~cm}$ wide by $12 \mathrm{~cm}$ deep) attached to the handheld component of the Li-Cor 6400 gas exchange unit (Li-Cor Biosciences, Lincoln, NE) (28). The $\mathrm{P}_{\mathrm{n}}$ units were $\mu \mathrm{mol}$ $\mathrm{CO}_{2} \mathrm{~m}^{-2} \mathrm{~s}^{-1}$, taken from a $78.5-\mathrm{cm}^{2}$ turfgrass canopy area. Each measurement required approximately $5 \mathrm{~min}$ and allowed photosynthesis and respiration to equilibrate within the chamber. Photosynthetic rate was measured from 1100 to $1600 \mathrm{~h}$ during cloud-free days each month within 3 days of the visual ratings for the putting green during 2001-02, and the microplots during 2002.

Statistical analyses. All statistical analyses were performed using SAS statistical software (SAS Institute, Cary, NC). Monthly correlation and regression analyses were used to investigate relationships among all the plant health measurements and nematode densities, as well as to establish the relationship of MSR and net photosynthetic rate values to bentgrass quality and cover ratings. Additionally, relationships within the six MSR measurements selected were determined. Because multiple MSR measures were similar in their capacity to detect lance nematode effects and measurements were highly correlated with each other, a rotated factor analysis was performed using PROC FACTOR. For example, on all dates, highest correlations (generally $r>0.90$ and $P \leq$ 0.01 ) occurred within the two groups of MSR data consisting of either three reflectance wavelengths or the three wavelengthcalculated indices. Orthogonal rotation was used to reduce subjectivity in factor interpretation (45). The rotated factor analysis partitions the variance of each

Table 1. Factor loadings and communalities (Comm) of a two-factor model for multispectral radiometry (MSR) variables in creeping bentgrass microplots artificially infested with Hoplolaimus galeatus

\begin{tabular}{|c|c|c|c|c|c|c|}
\hline \multirow[b]{3}{*}{ Canopy variable } & \multicolumn{6}{|c|}{ Factor loadings by year } \\
\hline & \multicolumn{3}{|c|}{2002} & \multicolumn{3}{|c|}{2003} \\
\hline & Factor 1 & Factor 2 & Comm & Factor 1 & Factor 2 & Comm \\
\hline 706-nm reflectance & 0.088 & 0.979 & 0.966 & 0.947 & -0.236 & 0.953 \\
\hline 760-nm reflectance & 0.235 & 0.962 & 0.981 & 0.954 & -0.279 & 0.988 \\
\hline 813-nm reflectance & 0.368 & 0.872 & 0.896 & 0.960 & -0.211 & 0.966 \\
\hline Chlorophyll index & 0.986 & 0.087 & 0.979 & -0.325 & 0.933 & 0.975 \\
\hline Leaf area index & 0.946 & 0.305 & 0.987 & -0.234 & 0.968 & 0.991 \\
\hline $\mathrm{NDVI}^{\mathrm{a}}$ & 0.942 & 0.289 & 0.971 & -0.184 & 0.967 & 0.968 \\
\hline Eigenvalues & 2.952 & 2.829 & $\ldots$ & 2.924 & 2.919 & $\ldots$ \\
\hline Proportion of total $\mathrm{S}^{2}$ & 0.695 & 0.268 & $\ldots$ & 0.720 & 0.254 & $\ldots$ \\
\hline
\end{tabular}

${ }^{\mathrm{a}} \mathrm{NDVI}=$ normalized difference vegetative index.

individual measurement to give greatest explanation of the total variance, with the first factor explaining the majority of the total variance. Each factor is ranked according to its eigenvalue and represents actual variance, with a minimum value of one set for factor retention in the analysis. MSR wavelengths and indices always grouped together into two separate factors. Therefore, the factor analysis both reduced the number of MSR variables and created factors that were independent of each other and uncorrelated. Correlation and regression analyses were used to investigate relationships between nematodes versus MSR factors, bentgrass quality and cover, photosynthetic rate, plant biomass or density, and root biomass.

Analysis of covariance (with nematode density as a covariate) was performed on extracted factors using Proc Mixed to assess the uniformity of nematode effects across management practices (cultivar, mowing height, and irrigation) to the putting green canopy. Intercept and slope estimates were used to contrast the direct effects of management practices on turf health and the interaction of management practice and nematode density, respectively.

\section{RESULTS}

Microplots. Canopy measurements. Monthly turfgrass quality ratings were positively correlated with MSR stressindicator wavelengths 706, 760, and 813 $\mathrm{nm}(r=0.21$ to $0.59, P \leq 0.1)$, and with MSR indices CI, LAI, and NDVI $(r=0.30$ to $0.69, P \leq 0.01)$ in both years of the study. In general, visual cover was not correlated to wavelengths but was positively correlated to indices in both years $(r$ $=0.37$ to $0.67, P \leq 0.01$ ).

Within-year factor analysis of the three MSR reflectance wavelengths and the three calculated indices resulted in two uncorrelated, positively loaded factors for each year (based on eigenvalues $\geq 1.0$ ), which together explained greater than $96 \%$ of the total variance in annual canopy measurements (Table 1). The analysis did not combine years because the two factors were loaded differently in 2002 and 2003.

1172 Plant Disease /Vol. 91 No. 9
For 2002, the first factor explained $70 \%$ of the total variance (Table 1). Highest loadings were for the MSR indices of CI, LAI, and NDVI, with lower loadings for the MSR wavelengths of 706, 760, and 813 $\mathrm{nm}$. The second factor was the inverse of the first, with highest loadings for the three wavelengths, and explained $27 \%$ of the total variance. For 2003, factor one was loaded principally for the three MSR wavelengths and explained $72 \%$ of the total variance (Table 1). Factor two was the inverse of factor one, with major loadings for MSR indices, and explained $25 \%$ of the total variance.

Communalities, indicating how well the model factors capture variance within each measure, also are included in Table 1. Across the two factors, individual MSR data were well described. Communalities of 90 to $99 \%$ in 2002 and $95 \%$ or greater in 2003 indicated that nearly all the variance was summarized regardless of loading during both years.

Nematode effects. $H$. galeatus population densities in microplots increased with time and reached levels exceeding $300 \mathrm{H}$. galeatus per $100 \mathrm{~g}$ of soil in August 2002 (47). The presence of $H$. galeatus in microplots was accompanied by both visual and physiological effects on creeping bentgrass during the 2002 and 2003 seasons. Correlations of individual MSR wavelengths and lance nematode densities varied by month, with negative correlations observed for far-red to near-infrared wavelengths (706, 760, and $813 \mathrm{~nm}$ ) in July 2002 and August 2003 (Fig. 1). Strong negative correlations with lance nematode densities also were observed for MSR indices (CI, LI, and NDVI) during August and September of both years $(r=$ -0.42 to $-0.63, P \leq 0.1)$.

Correlations of lance nematode population densities with visual quality and cover ratings and factors representing MSR variables were similarly dependent on month (Table 2). In late summer of both years, the factor strongly loaded for MSR indices was negatively correlated with nematode density (i.e., factor 1 during September 2002 and factor 2 during August and September 2003), whereas the factor strongly loaded for MSR wavelengths was negatively correlated with nematodes only in August 2003. Bentgrass quality ratings, however, were consistently more highly negatively correlated ( $r=-0.39$ to $-0.58 ; P$ $\leq 0.01)$ with nematode densities than $P_{n}$, MSR variables, or factor models of MSR variables (Table 2). Lance nematode population densities were associated with decreasing bentgrass quality during the summers of 2002 and 2003, except in June and August 2002 (Fig. 2). Nematode populations associated with unacceptable bentgrass quality (rating $\leq 6.0$ ) varied from 177 to $845 \mathrm{H}$. galeatus per $100 \mathrm{~g}$ of soil in June and September 2003, respectively. September quality ratings in both years de- 
creased an average of $10 \%$ (one bentgrass visual quality unit) for each increase in 400 nematodes per $100 \mathrm{~g}$ of soil (Fig. 2).

Monthly root biomass measurements were taken in August and September 2002 and June through September 2003. No correlations were found between nematode populations and total root biomass at two soil depths. Root biomass at the 6- to 16$\mathrm{cm}$ but not the 1- to 6-cm soil depth was negatively correlated with $H$. galeatus populations in July, August, and Septem- ber 2003 (Fig. 3). On the other sampling dates, correlations between nematodes and root biomass were absent even though negative visual effects were detected on two of those dates (Fig. 2). Aboveground plant shoot density was negatively corre-
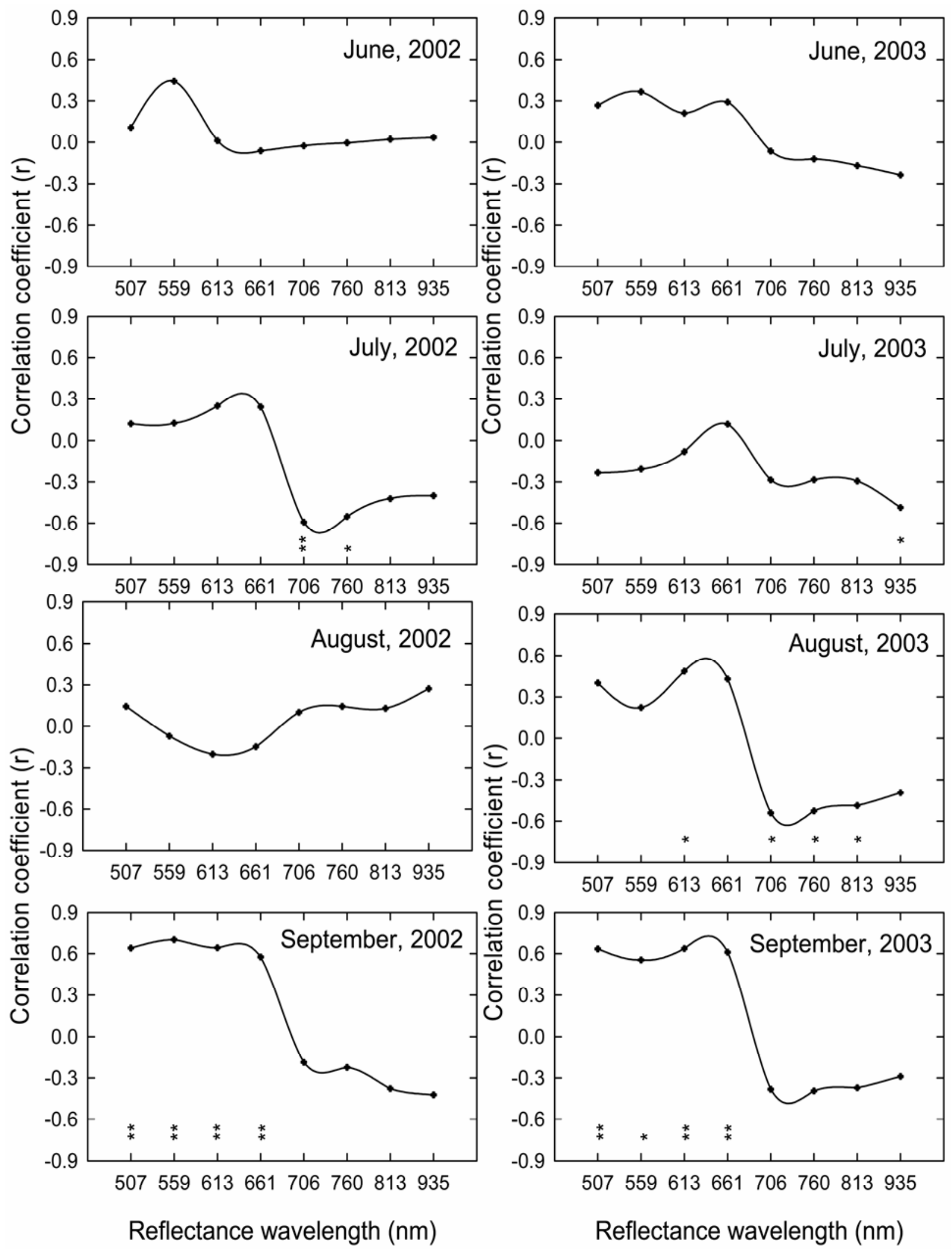

Fig. 1. Correlations of A-4 creeping bentgrass multispectral radiometry reflectance wavelengths with Hoplolaimus galeatus population densities in microplots from June to September 2002 and 2003. Correlations at * and ** are significant at $P \leq 0.05$ and 0.01 , respectively. 
lated $(P \leq 0.05)$ with nematode populations in June $(r=-0.46)$ and July $(r=$ -0.52) 2003, but not on other dates.

Putting green. Canopy measurements. Bentgrass quality ratings and MSR measurements of the naturally infested putting green were positively correlated $(P \leq 0.05)$ on all dates $(r=0.48$ to 0.88 in 2001 and 0.21 to 0.74 in 2002). Similarly, $P_{n}$ was positively correlated $(P \leq 0.01)$ with bentgrass quality from July to September 2001 (average $r=0.51)$ and in July $2002(r=$ 0.38 ). In contrast, monthly cover ratings frequently were not correlated with MSR measurements or $\mathrm{P}_{\mathrm{n}}$ in either year (data not shown).

Two positively loaded factors explained 99 and $93 \%$ of the total variance among six MSR canopy measurements in 2001 and 2002, respectively (Table 3). Years were not combined in the analysis because the two factors were loaded differently each year. For 2001, factor one, which explained $84 \%$ of the total variance, was loaded principally for the three MSR wavelengths of 706, 760, and 813 $\mathrm{nm}$, with lower loadings for the three MSR indices CI, LAI, and NDVI, (Table 3 ). Factor two, which explained $15 \%$ of the total variance, was the inverse of factor one, with principal loadings of the three indices (Table 3). Individual MSR measurements were explained by communalities $\geq 97 \%$. The loading pattern in 2002 was similar to 2001 , with indices and wavelengths grouping together within separate factors, and each represented the inverse of the other (Table 3). However, factor one was now loaded principally for indices and factor two for wavelengths. Factor one and two explained 64 and 29\% of the total variance of all MSR canopy measurements, respectively. Across the two factors, communalities for individual MSR measurements, except $813 \mathrm{~nm}$, were $\geq 93 \%$ (Table 3).

Cultivar and management practicesdirect effects. Cultivar, irrigation frequency, and mowing height cultural practices affected bentgrass quality and cover as well as MSR factors in 2001, but effects frequently varied with month (Table 4). For example, maximum visual quality differences among cultivars $(P \leq 0.05)$ occurred during June and July (data not shown). During June, L-93 and Providence had better visual quality ( 8.3 and $8.1 ; 90 \%$ of optimum) compared with Penncross and Crenshaw (6.8 and $6.7 ; 75 \%$ of optimum). In July, L-93 had better quality $(7.7 ; 86 \%$ of optimum) compared with the other cultivars, which exhibited nearly identical quality $($ mean $=6.1 ; 68 \%$ of optimum). After midsummer, bentgrass quality differences were more subtle and the range across all cultivars was 0.6 in August and 1.0 in September. Daily irrigation reduced $(P \leq 0.05)$ factor 1 (individual wavelengths), $\mathrm{P}_{\mathrm{n}}$, and quality compared with alternate-day-irrigated plots in late summer, with the greatest effects observed for August. Reduced mowing height generally was associated with lower $(P \leq 0.05)$ health indicator ratings, except for cover, in all months. Plots mowed at $3.2 \mathrm{~mm}$ had an average visual quality rating of 6.0 (67\% of optimum) compared with a rating of 7.2 (80\% of optimum) at the $4.0-\mathrm{mm}$ clipping height. In 2002, cultivar, irrigation frequency, and mowing height had less effect on all turf variables. Penncross, but not the other cultivars, exhibited lower visual quality $(P \leq 0.05)$ with alternate-day irrigation in August. As in 2001, lower mowing heights reduced $(P \leq 0.05)$ both MSR factors and $\mathrm{P}_{\mathrm{n}}$.

Interaction of nematode and management stresses. The relationship between $H$. galeatus population density and turf health varied between years and, in 2002, among management practices (Table 4). In that year, interactions between nematode density and irrigation frequency or mowing height were observed for all measurement variables except for factor 2 , which was loaded for the individual MSR wavelengths. Visual quality and cover both declined $(P \leq 0.05)$ with increasing nematode densities in plots with either reduced irrigation frequency or greater mowing height (Fig. 4). In contrast, the MSR indicesloaded factor 1 increased with increasing nematode densities under daily irrigation (data not shown). H. galeatus contributed to reduced $(P \leq 0.05) \mathrm{P}_{\mathrm{n}}$ in Crenshaw under alternate-day irrigation in 2001 and in daily irrigated Penncross in both years (Fig. 5).

\section{DISCUSSION}

The most consistent indicators of lance nematode damage in microplots were quality and cover ratings. Individual MSR wavelengths and indices also detected the effects of high nematode populations but were not as consistent as bentgrass quality ratings. The factor loaded with individual MSR wavelengths was not correlated with nematode populations in September 2002 or 2003 during a period when all other canopy measurements were negatively correlated. This indicates that physiological effects caused by $H$. galeatus may not be reliably detected by MSR reflectance bands that represent the far-red to nearinfrared wavelength region. This region is capable of detecting plant diseases such as late blight of tomato (61) and Cercospora leaf spot of sugar beet (Beta vulgaris L.) (50) that cause distinct leaf chlorosis and necrosis, but may be less effective in identifying more subtle color and turf quality changes resulting from nematode feeding. In our study, MSR measurements of indices and wavelengths always were represented independently by uncorrelated factors and, typically, were not simultaneously correlated with nematode populations. This suggests that these two types of canopy reflectance data capture unique physiological characteristics of creeping bentgrass.

There are numerous benefits of using MSR methods to quantify diseases compared with visual ratings. MSR reflectance data allows observers to independently acquire standardized data from multiple locations, increases the feasibility of conducting long-term research, and potentially can aid the development and improvement of predictive models (50). Nevertheless, we found that bentgrass quality and cover ratings taken by a single, well-trained visual rater was the most consistent method of sensing foliar symptoms associated with lance nematode damage to creeping bentgrass. Net photosynthetic rate also provided a measure of nematode injury in both the microplots and, in some cases, the naturally infested putting green. However, these measurements were the most time consuming when compared with MSR and visual ratings, and required two to three consecutive days to complete all 96 field

Table 2. Correlation analysis of bentgrass quality ratings and multispectral radiometry (MSR) factors to Hoplolaimus galeatus population densities in creeping bentgrass microplots

\begin{tabular}{|c|c|c|c|c|c|c|c|c|c|c|}
\hline \multirow[b]{3}{*}{ Lance } & \multicolumn{10}{|c|}{ Correlations of factor loadings to $H$. galeatus populations ${ }^{\text {a }}$} \\
\hline & \multicolumn{5}{|c|}{2002} & \multicolumn{5}{|c|}{2003} \\
\hline & Factor 1 & Factor 2 & Quality & Turf cover & Rate & Factor 1 & Factor 2 & Quality & Turf cover & Rate \\
\hline June & 0.015 & -0.005 & 0.128 & -0.010 & -0.285 & -0.143 & -0.246 & $-0.708^{* *}$ & $-0.541 *$ & $\ldots$ \\
\hline July & -0.267 & -0.347 & $-0.485^{*}$ & $-0.551 *$ & -0.226 & -0.294 & -0.262 & $-0.559 *$ & -0.335 & $\ldots$ \\
\hline August & -0.440 & -0.021 & -0.431 & -0.325 & -0.426 & $-0.531 *$ & $-0.513^{*}$ & $-0.569^{* *}$ & -0.151 & $\ldots$ \\
\hline September & $-0.573^{* *}$ & -0.015 & $-0.668 * *$ & $-0.672 * *$ & $-0.500^{*}$ & -0.418 & $-0.528 *$ & $-0.762 * *$ & $-0.627 * *$ & $\ldots$ \\
\hline Year & -0.163 & -0.182 & $-0.340 * *$ & $-0.270^{*}$ & $-0.307 * *$ & $-0.413 * *$ & 0.041 & $-0.534 * *$ & $0.224^{*}$ & $\ldots$ \\
\hline
\end{tabular}

a Correlations: $*$ and $* *$ indicate significant at $P \leq 0.05$ and 0.01 , respectively. Factors consisted of reflectance wavelengths 706,760 , and 813 nm or reflectance indices of chlorophyll, leaf area, and normalized difference vegetation. Lance $=$ lance nematodes, Quality $=$ bentgrass quality, Turf cover $=$ turfgrass cover, and Rate = photosynthetic rate. 
plot measurements. Furthermore, we found that cloud cover on some days interfered with both photosynthesis and MSR measurements and slowed the rating process. In contrast, turfgrass quality and cover were less affected by overcast conditions, which typically help visual ratings by reducing the glare of reflected sunlight.
There have been several attempts to quantify lance nematode population densities that may result in visible turfgrass injury and warrant nematicide applications
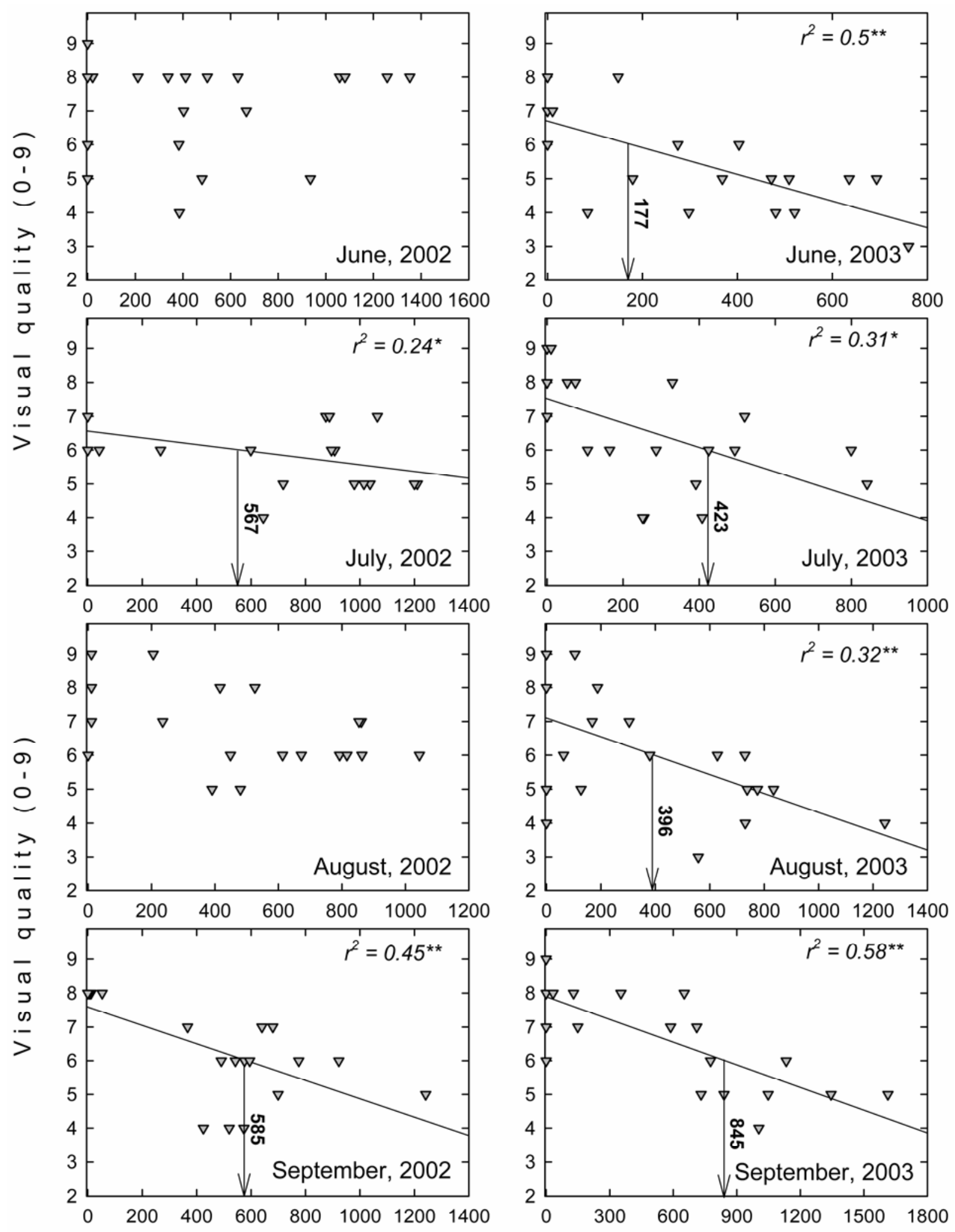

H. galeatus per $100 \mathrm{~g} \mathrm{soil}$

Fig. 2. Regression analyses of A-4 creeping bentgrass quality to Hoplolaimus galeatus population densities in artificially infested putting green microplots from June to September 2002 and 2003. Quality ratings ranged from 0 to 9 , where $0=$ dead, $9=$ no damage, and $6=$ minimum acceptable quality. Monthly population damage threshold (quality $\leq 6$ ) is indicated with arrow. Regressions at * and ** are significant at $P \leq 0.05$ and 0.01 , respectively. 
$(5,16,52)$. Todd and Tisserat (52) found that densities above $300 \mathrm{H}$. galeatus per $100 \mathrm{~cm}^{3}$ of soil in a creeping bentgrass putting green were associated with unacceptable turf quality in July, but their estimate was limited to visual effects observed in only 1 of 3 years. They suggested that damage thresholds could fluctuate during the growing season depending on environmental factors and overall bentgrass health. Our microplot data support their hypothesis. The H. galeatus population density that was associated with an unacceptable level of turfgrass damage varied monthly and actually increased nearly fourfold during summer 2003. Similarly, the predicted threshold for unacceptable injury varied by as much as 260 nematodes per $100 \mathrm{~g}$ of soil for the same month (September) in separate years (2002 and 2003), likely as a result of a combination of more stressful environmental conditions for turfgrass growth and more conducive conditions for nematode population increase in 2002, which was warmer and wetter than 2003. Nematode population densities, for example, peaked 2 months earlier in 2002 compared with 2003 (July compared with September, respectively).

The effect of $H$. galeatus populations on bentgrass health, as evidenced by multiple negative correlations with turfgrass quality and cover, $\mathrm{P}_{\mathrm{n}}$, and reflectance indices, was most apparent in September of each year. Because sampling and measurements were conducted during the first week of each month, September ratings actually represented conditions during mid- to late $\mathrm{Au}$ gust, when soil and air temperatures were high and bentgrass, presumably, was under maximum environmental stress. $H$. galeatus reproduction rates are favored by warm soil temperatures (48) and populations tend to peak in mid- to late summer (47). In contrast, bentgrass root growth is inhibited by high or supraoptimal temperatures (13). Intensified feeding by a large nematode population on a more or less static root system could result in root damage and decreased turf quality. This hypothesis is supported by the negative correlations between root biomass and $H$. galeatus populations observed in this study. Similarly, Davis et al. (8) reported that the stunt nematode ( $T$. nudus) reduced creeping bentgrass root length as soil temperatures were increased from 24 to $30^{\circ} \mathrm{C}$. However, high soil temperatures, poor soil aeration, and low mowing heights also contribute to root mortality in summer $(19,20,60)$, potentially interacting with or even masking nematode effects belowground. This may explain why nematode-related reductions


\section{H. galeatus per $100 \mathrm{~g}$ soil}

Fig. 3. Regression analyses of A-4 creeping bentgrass root biomass at 6- to 16-cm depth to Hoplolaimus galeatus population densities in artificially infested putting green microplots from June to September 2003. Regressions at * and ** are significant at $P \leq 0.05$ and 0.01 , respectively. 
in root biomass were detected inconsistently in our study. For example, lance nematode populations first were associated with negative canopy effects beginning in summer 2002, but were not associated with root reductions until the following year.

In spring 2003, we observed injury to bentgrass in microplots following winter desiccation. Damage was more severe in plots with high $H$. galeatus populations and resulted in a strong negative correlation between bentgrass quality and nematode populations in June 2003. Bentgrass injury and slow spring recovery may have reflected root dysfunction caused by the cumulative negative effect of impaired water uptake in roots damaged by lance nematodes from the previous summer or fall. Alternatively, nematode feeding on damaged roots in spring may have contributed to reduced bentgrass quality. Davis et al. (9) observed that the stunt nematode reduced root biomass of a dormant creeping bentgrass putting green in March.

We found that bentgrass cultivar, mowing height, and irrigation frequency influenced bentgrass health during the summer. In general, bentgrass mowed at the lower height had lower-quality ratings and $P_{n}$ in midsummer, and this effect was more pronounced for cv. Penncross. Our results are similar to previous studies, which showed that management practices that increase physiological stress on bentgrass adversely affect quality or $\mathrm{P}_{\mathrm{n}}$ in midsummer (26-28). We also observed interactions between management-related stresses and nematode injury, but these interactions were inconsistent and difficult to predict. Some management practices maintained acceptable bentgrass quality even in the presence of relatively high population densities of lance nematodes, suggesting that golf

Table 3. Factor loadings and communalities (Comm) of two-factor models for canopy measurements in an experimental creeping bentgrass putting green naturally infested with Hoplolaimus galeatus

\begin{tabular}{|c|c|c|c|c|c|c|}
\hline \multirow[b]{3}{*}{ Canopy variable } & \multicolumn{6}{|c|}{ Factor loadings by year } \\
\hline & \multicolumn{3}{|c|}{2001} & \multicolumn{3}{|c|}{2002} \\
\hline & Factor 1 & Factor 2 & Comm & Factor 1 & Factor 2 & Comm \\
\hline $706 \mathrm{~nm}$ reflectance & 0.906 & 0.387 & 0.970 & -0.030 & 0.965 & 0.931 \\
\hline $760 \mathrm{~nm}$ reflectance & 0.947 & 0.310 & 0.993 & 0.211 & 0.950 & 0.947 \\
\hline $813 \mathrm{~nm}$ reflectance & 0.931 & 0.343 & 0.984 & 0.454 & 0.755 & 0.776 \\
\hline Chlorophyll index & 0.203 & 0.973 & 0.988 & 0.969 & 0.023 & 0.939 \\
\hline Leaf area index & 0.498 & 0.863 & 0.992 & 0.971 & 0.226 & 0.994 \\
\hline $\mathrm{NDVI}^{\mathrm{a}}$ & 0.539 & 0.827 & 0.974 & 0.959 & 0.259 & 0.987 \\
\hline Eigenvalues & 3.162 & 2.739 & $\ldots$ & 3.053 & 2.521 & $\ldots$ \\
\hline Proportion of total $\mathrm{S}^{2}$ & 0.838 & 0.151 & $\ldots$ & 0.638 & 0.291 & $\ldots$ \\
\hline
\end{tabular}

a NDVI = normalized difference vegetative index . course superintendents could influence or possibly avoid putting green injury due to this nematode; however, $\mathrm{P}_{\mathrm{n}}$ measurements indicated that the interaction of stresses resulting from nematode feeding and management decisions is cultivar dependent. Overall, bentgrass management decisions must be dynamic and optimized by prevailing environmental conditions with the goal of accommodating plant health of an individual putting green area.

Nematode damage itself was more difficult to quantify for the putting green compared with the artificially infested microplots, despite similar $H$. galeatus population densities in both studies (47). Nematode populations in the putting green were spatially aggregated and were not temporally stable (47), and this may have influenced our ability to consistently detect damage relationships among cultivars and management practices that were spatially fixed during the course of the experiment. Another possibility is that harmful management practices such as a low mowing height may have masked any injury resulting from nematode feeding. Whatever the case, our results illustrate the complex relationship of $H$. galeatus to bentgrass, and the difficulty in assessing nematode effects under conditions that would occur normally on golf course putting greens.

In summary, we demonstrated in microplot studies that $H$. galeatus populations are capable of damaging creeping bentgrass and that this damage can be assessed by visual and MSR measurements. In this study, a well-trained human

Table 4. Analysis of covariance for cultivar and management practice effects on the relationship between visual and multispectral radiometry measurements and Hoplolaimus galeatus population densities in a naturally infested creeping bentgrass putting green

\begin{tabular}{|c|c|c|c|c|c|c|c|c|c|c|}
\hline \multirow[b]{3}{*}{ Canopy variable } & \multicolumn{10}{|c|}{$F$ value $^{\mathrm{a}}$} \\
\hline & \multicolumn{5}{|c|}{2001} & \multicolumn{5}{|c|}{2002} \\
\hline & Factor 1 & Factor 2 & Quality & Cover & $\mathbf{P}_{\mathbf{n}}$ & Factor 1 & Factor 2 & Quality & Cover & $\mathbf{P}_{\mathbf{n}}$ \\
\hline Month (MO) & $30.78 * *$ & $78.43 * *$ & $15.29 * *$ & $6.30 *$ & 1.87 & $23.99 * *$ & $8.23 *$ & 2.83 & 0.15 & $7.94 *$ \\
\hline Cultivar (CV) & 3.65 & $7.78 *$ & $8.20 *$ & 0.23 & 2.85 & 3.65 & 0.68 & 4.08 & 0.39 & 0.18 \\
\hline $\mathrm{MO} \times \mathrm{CV}$ & $2.86 * *$ & $2.29 *$ & $2.38 *$ & $2.46^{*}$ & 0.86 & 1.20 & 1.08 & 1.79 & 1.24 & 1.06 \\
\hline Irrigation frequency (IRR) & $150.67 * *$ & 0.37 & $26.42^{*}$ & 12.48 & $26.48 *$ & 0.50 & 1.95 & 0.01 & 0.61 & 0.04 \\
\hline $\mathrm{MO} \times \mathrm{IRR}$ & $22.76 * *$ & 0.60 & $7.96 * *$ & 2.47 & $8.72 * *$ & 1.56 & $6.42 * *$ & 0.64 & $3.35^{*}$ & 2.10 \\
\hline $\mathrm{CV} \times \mathrm{IRR}$ & 2.19 & 1.43 & 2.01 & 0.08 & 3.22 & 0.70 & 1.45 & 1.21 & 0.84 & $6.38^{*}$ \\
\hline $\mathrm{MO} \times \mathrm{CV} \times \mathrm{IRR}$ & 0.69 & 0.67 & 0.81 & 1.01 & 0.56 & 1.40 & 0.96 & $2.04 *$ & $2.05^{*}$ & 1.25 \\
\hline Clipping height (HT) & $139.32 * *$ & $51.64 * *$ & $39.47 * *$ & 0.77 & $47.16 * *$ & $13.18 * *$ & $20.55 * *$ & 1.97 & 2.90 & $23.47 * *$ \\
\hline $\mathrm{MO} \times \mathrm{HT}$ & $7.38 * *$ & $6.58 * *$ & 2.33 & $7.81 * *$ & 1.79 & 1.54 & 2.32 & 0.40 & 0.53 & 0.24 \\
\hline $\mathrm{CV} \times \mathrm{HT}$ & 2.35 & 1.05 & 1.02 & 1.85 & 1.01 & 0.95 & 0.75 & 1.45 & 0.96 & 0.55 \\
\hline $\mathrm{MO} \times \mathrm{CV} \times \mathrm{HT}$ & 0.50 & 0.76 & 0.63 & 1.94 & 0.75 & 0.43 & 1.02 & 0.31 & 0.93 & 0.86 \\
\hline $\mathrm{IRR} \times \mathrm{HT}$ & $9.38 *$ & 0.05 & 2.22 & 0.00 & 1.14 & 0.05 & 1.21 & 1.05 & 0.01 & 0.75 \\
\hline $\mathrm{MO} \times \mathrm{IRR} \times \mathrm{HT}$ & $4.32 * *$ & 0.62 & 1.62 & 2.37 & 0.59 & 0.21 & 1.63 & 0.17 & 0.27 & 1.08 \\
\hline $\mathrm{CV} \times \mathrm{IRR} \times \mathrm{HT}$ & 2.65 & 1.57 & 0.76 & 2.33 & 1.40 & 0.17 & 0.46 & 0.99 & 0.49 & 1.47 \\
\hline $\mathrm{MO} \times \mathrm{CV} \times \mathrm{IRR} \times \mathrm{HT}$ & 0.59 & 0.56 & 0.33 & 0.95 & 0.95 & 0.45 & 0.23 & 0.64 & 0.86 & 1.35 \\
\hline Hoplolaimus galeatus (HG) & 2.63 & 1.07 & 0.98 & 0.01 & 3.44 & 0.50 & 1.39 & 2.68 & $5.72 *$ & 0.18 \\
\hline $\mathrm{HG} \times \mathrm{CV}$ & 2.34 & $2.70 *$ & 1.10 & 0.02 & $2.70 *$ & 1.59 & 0.85 & 2.24 & 1.06 & 1.08 \\
\hline $\mathrm{HG} \times \mathrm{IRR}$ & 1.08 & 0.04 & 0.90 & 0.22 & 2.86 & $7.63 * *$ & 1.69 & 2.91 & $8.12 * *$ & 0.03 \\
\hline $\mathrm{HG} \times \mathrm{CV} \times \mathrm{IRR}$ & 0.23 & 0.86 & 0.25 & 0.14 & $3.28 *$ & 1.42 & 0.43 & 0.90 & 0.82 & $5.15^{* *}$ \\
\hline $\mathrm{HG} \times \mathrm{HT}$ & 0.10 & 1.53 & 0.42 & 0.21 & 0.97 & 1.56 & 2.47 & $4.61 *$ & $7.81 * *$ & 2.55 \\
\hline $\mathrm{HG} \times \mathrm{CV} \times \mathrm{HT}$ & 1.84 & 1.52 & 0.53 & 1.01 & 0.77 & 0.68 & 0.17 & 2.43 & 0.93 & 0.35 \\
\hline $\mathrm{HG} \times \mathrm{IRR} \times \mathrm{HT}$ & 0.80 & 1.01 & 0.13 & 0.00 & 1.11 & 0.58 & 2.01 & 0.47 & 0.09 & 0.02 \\
\hline $\mathrm{HG} \times \mathrm{CV} \times \mathrm{IRR} \times \mathrm{HT}$ & 0.80 & 2.13 & 0.81 & 0.87 & 1.90 & 0.66 & 1.01 & 0.67 & 1.19 & 1.49 \\
\hline $\mathrm{HG} \times \mathrm{MO} \times \mathrm{CV} \times \mathrm{IRR} \times \mathrm{HT}$ & 0.73 & 0.68 & 0.81 & 0.73 & 0.88 & 1.17 & 0.89 & 1.37 & 1.36 & 1.01 \\
\hline
\end{tabular}

a Correlations: $*$ and $* *$ indicate significant at $P \leq 0.05$ and 0.01 , respectively. Factors consisted of reflectance wavelengths of 706,760 , and 813 nm or reflectance indices of chlorophyll, leaf area, and normalized difference vegetation. $\mathrm{P}_{\mathrm{n}}=$ net photosynthetic rate. 

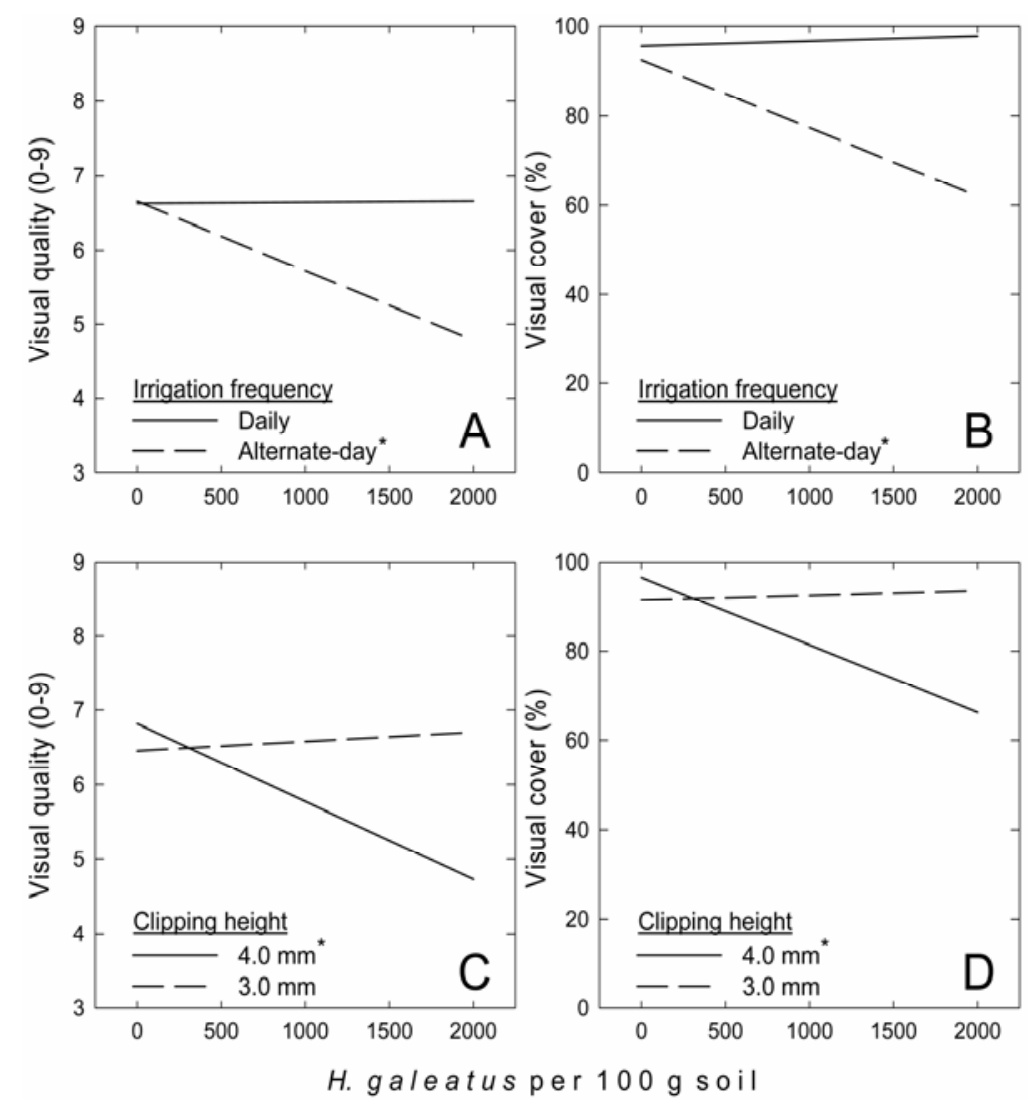

Fig. 4. Regression analysis of irrigation frequency effects on creeping bentgrass $\mathbf{A}$, visual quality and $\mathbf{B}$, visual cover, as well as clipping height effects on $\mathbf{C}$, visual quality and $\mathbf{D}$, visual cover to Hoplolaimus galeatus population densities in a putting green from June to September 2002. Treatment slopes significantly different from 0 are signified by an asterisk $(*)$ on each legend $(P \leq 0.05)$.

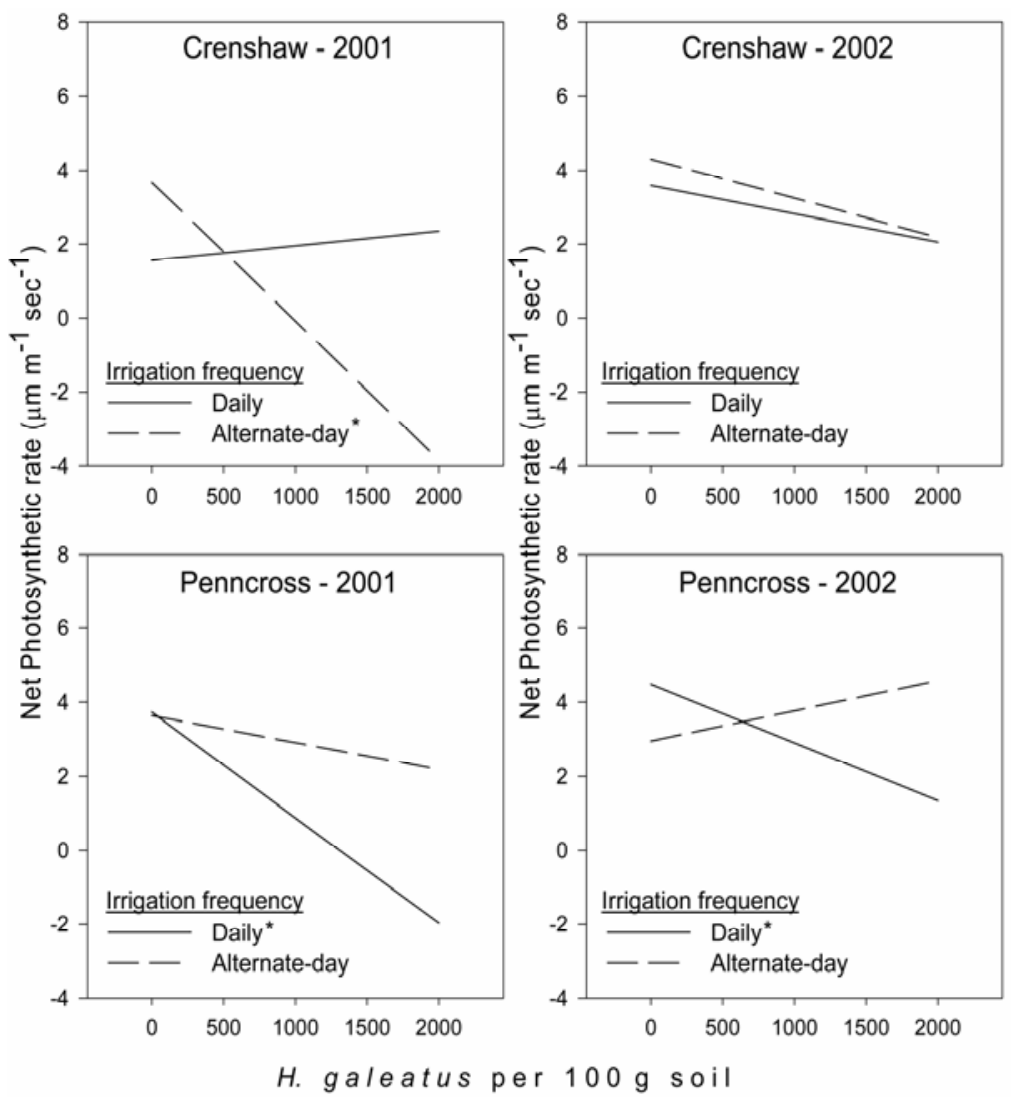

Fig. 5. Regression analysis of irrigation frequency effects on creeping bentgrass net photosynthetic rate to Hoplolaimus galeatus population densities in a putting green from June to September 2001 and 2002. Irrigation treatment slopes significantly different from 0 are signified by an asterisk $\left(^{*}\right)$ on each legend $(P \leq 0.05)$. eye could consistently detect lance nematode injury to bentgrass, and the electronic methods employed were not better at detecting what often were subtle canopy effects. We observed temporal variation in nematode damage thresholds associated with unacceptable turfgrass quality and, in the case of the putting green, demonstrated that the contribution of nematode populations to declines in bentgrass health varied with environment and management practice. We believe that static damage thresholds of lance nematodes in creeping bentgrass are of questionable value and actually may contribute to confusion in understanding the dynamic host-parasite relationship that exists between rootfeeding nematodes and turfgrass. Our results further suggest that, as long as management practices are optimized, golf putting greens can tolerate relatively high levels of nematode feeding pressure before declines in visual quality become unacceptable. Ultimately, damage caused by $H$. galeatus feeding must be placed in context of bentgrass injury resulting from adverse management practices such as low mowing heights and suboptimal watering regimes. Unacceptable turfgrass quality can result from stresses due to the environment, management practice, nematode feeding pressure, or, more likely, a combination of all three. Therefore, the use of a single population threshold as a basis for implementing management strategies is unreliable and if, as in this case, nematicide application is one of a limited number of responses, accompanied by some risk of undesirable consequences.

\section{LITERATURE CITED}

1. Asrar, G., Fuchs, M., Kanemasu, E. T., and Hatfield, J. L. 1984. Estimating absorbed photosynthetic radiation and leaf-area index from spectral reflectance in wheat. Agron. J. 76:300306.

2. Bell, G. E., Martin, D. L., Stone, M. L., Solie, J. B., and Johnson, G. V. 2002. Turf area mapping using vehicle-mounted optical sensors Crop Sci. 42:648-651.

3. Carter, G. A. 1993. Responses of leaf spectral reflectance to plant stress. Am. J. Bot. 80:239243.

4. Carter G. A., and Knapp, A. K. 2001. Leaf optical properties in higher plants: linking spectral characteristics to stress and chlorophyll concentration. Am. J. Bot. 88:677-684.

5. Couch, H. B. 1995. Diseases of Turfgrasses. 3rd ed. Robert E. Krieger Publishing Co., Huntington, NY.

6. Davis, J. G., and Dernoeden, P. H. 2002. Dollar spot severity, tissue nitrogen, and soil microbial activity in bentgrass as influenced by nitrogen source. Crop Sci. 42:480-488.

7. Davis, R. F., Kane, R. T., Wilkinson, H. T., and Noel, G. R. 1994. Population fluctuations of three nematode genera in putting greens in northern Illinois. J. Nematol. 26:522-530.

8. Davis, R. F., Wilkinson, H. T., and Noel, G. R. 1994. Root growth of bentgrass and annual bluegrass as influenced by coinfection with $T y$ lenchorhynchus nudus and Magnaporthe poae. J. Nematol. 26:86-90.

9. Davis, R. F., Wilkinson, H. T., and Noel, G. R. 1994. Vertical distribution of three nematode genera in a bentgrass putting green in central 
Illinois. J. Nematol. 26:518-521.

10. Dudka, M., Langton, S., Schuler, R., Kurle, J., and Grau, C. R. 1998. Use of digital imagery to evaluate disease incidence and yield loss caused by Sclerotinia stem rot of soybeans. In: Proc. 1998 Int. Precision Agric. Conf. St. Paul, MN.

11. Eckles, R. D., Welles, J. M., and Peterson, K. 1993. $\mathrm{CO}_{2}$ and $\mathrm{CO}_{2} / \mathrm{H}_{2} \mathrm{O}$ infrared gas analyzers. Measure. Control 161:83-89.

12. Feng, Y., and Dernoeden, P. H. 1999. Pythium species associated with root dysfunction of creeping bentgrass in Maryland. Plant Dis. 83:516-520.

13. Fry, J. D., and Huang, B. 2004. Applied Turfgrass Science and Physiology. John Wiley and Sons, Hoboken, NJ.

14. Gausman, H. W., Heald, C. M., Jr., and Escobar, D. E. 1975. Effect of Rotylenchus reniformis on reflectance of cotton plant leaves. J. Nematol. 4:368-374.

15. Gent, M. P. N., LaMondia, J. A., Ferrandino, F. J., Elmer, W. H., and Stoner, K. A. 1999. The influence of compost on the reduction of gas exchange in potato by Verticillium dahliae and Pratylenchus penetrans. Plant Dis. 83:371-376.

16. Giblin-Davis, R. M., Busey, P., and Center, B. J. 1995. Parasitism of Hoplolaimus galeatus on diploid and polyploidy St. Augustinegrasses. J. Nematol. 27:472-477.

17. Guan, J., and Nutter, F. W., Jr. 2002. Relationships between percentage defoliation, dry weight, percentage reflectance, leaf-to-stem ratio, and green leaf area index in the alfalfa leaf spot pathosystem. Crop. Sci. 42:1264-1273.

18. Hatfield, J. L., Kanemasu, E. T., Asrar, G., Jackson, R. D., Pinter Jr., P. J., Regiato, R. J., and Idso, S. B. 1983. Leaf area estimators from spectral measurements over various planting dates of wheat. Int. J. Remote Sens. 53:385-388.

19. Huang, B., Liu, X., and Fry, J. D. 1998. Effects of high temperature and poor soil aeration on root growth and viability of creeping bentgrass. Crop Sci. 38:1618-1622.

20. Huang, B., Liu, X., and Xu, Q. 2001. Supraoptimal soil temperatures induced oxidative stress in leaves of creeping bentgrass cultivars differing in heat tolerance. Crop Sci. 41:430435.

21. Jackson, R. D. 1986. Remote sensing of biotic and abiotic plant stress. Annu. Rev. Phytopathol. 24:265-287.

22. Jenkins, W. 1964. A rapid centrifugal-flotation technique for separating nematodes from soil. Plant Dis. Rep. 48:692.

23. Koenning, S. R., and Barker, K. R. 1995. Soybean photosynthesis and yield as influenced by Heterodera glycines, soil type and irrigation. J. Nematol. 27:51-62.

24. Koh, K. J., Bell, G. E., Martin, D. L., and Walker, N. R. 2003. Shade and airflow restriction effects on creeping bentgrass golf greens. Crop Sci. 43:2182-2188.

25. Laughlin, C. W., and Vargas, J. M., Jr. 1972. Pathogenic potential of Tylenchorhynchus dubius on selected turfgrass. J. Nematol. $4: 277-279$

26. Liu, X., and Huang, B. 2001. Seasonal changes and cultivar differences in turf quality, photosynthesis, and respiration of creeping bentgrass. HortScience 36:1131-1135.

27. Liu, X., and Huang, B. 2002. Mowing effects on root production, growth, and mortality of creeping bentgrass. Crop Sci. 42:1241-1250.

28. Liu, X., and Huang, B. 2003. Mowing height effects on summer turf growth and physiological activities for two creeping bentgrass cultivars. HortScience 38:444-448.

29. Loveys, B. R., and Bird, A. F. 1973. The influence of nematodes on photosynthesis in tomato plants. Physiol. Plant Pathol. 3:525-529.

30. Loveys, B. R., and Bird, A. F. 1974. The incorporation of photosynthates by Meloidogyne javanica. J. Nematol. 7:111-113.

31. Lukens, R. J., and Miller, P. M. 1973. Injury to turf grasses by Tylenchorhynchus dubius and Hoplolaimus spp. (Abstr.) Phytopathology 63:204

32. Melakeberhan, H., and Ferris, H. 1989. Impact of Meloidogyne incognita on physiological efficiency of Vitis vinifera. J. Nematol. 21:74-80.

33. Melakeberhan, H., Ferris, H., and, Dias, J. M. 1990. Physiological response of resistant and susceptible Vitis vinifera cultivars to Meloidogyne incognita. J. Nematol. 22:224-230.

34. Melakeberhan H., Webster, J. M., Brooke, R.C., D'Auria, J. M., and Cackette, M. 1987. Effect of Meloidogyne incognita on plant nutrient concentration and its influence on the physiology of beans. J. Nematol. 19:324-330.

35. Merzlyak, M. N., Gilteson, A. A., Chivkunova, O. B., Solovchenko, A. E., and Pogosyan, S. I. 2003. Application of reflectance spectroscopy for analysis of higher plant pigments. Russ. J. Plant Physiol. 50:704-710.

36. Michell, R. E., Malek, R. B., Taylor, D. P., and Edwards, D. I. 1973. Races of the barley rootknot nematode, Meloidogyne naasi. III. Reproduction and pathogenicity on creeping bentgrass. J. Nematol. 5:47-49.

37. Nendick, D. K., and Noe, J. P. 1994. Effects of Hoplolaimus columbus on photosynthesis and yield on cotton. J. Nematol. 26:112

38. Nilsson, H. 1995. Remote sensing and image analysis in plant pathology. Can. J. Plant Pathol. 17:154-166.

39. Nutter, F. W., Jr., Gleason, M. L., Jenco, J. H., and Christians, N. C. 1993. Assessing the accuracy, intra-rater repeatability, and inter-rater reliability of disease assessment systems. Phytopathology 83:806-812.

40. Nutter, F. W., Jr., Guan, J., Gotlieb, A. R., Rhodes, L. H., Grau, C. R., and Sulc, R.M. 2002. Quantifying alfalfa yield losses caused by foliar diseases in Iowa, Ohio, Wisconsin, and Vermont. Plant Dis. 86:269-277.

41. Nutter, F. W., Jr., Littrell, R. H., and Brenneman, T. B. 1990. Utilization of a multispectral radiometer to evaluate fungicide efficacy to control late leaf spot in peanut. Phytopathology 80:102-108.

42. Raikes, C., and Burpee, L. L. 1998. Use of multispectral radiometry for assessment of Rhizoctonia blight in creeping bentgrass. Phytopathology 88:446-449.

43. Rhinehart, G. J., Baird, J. H., Calhoun, R. N., and Schabbenberger, O. 2001. Remote sensing of brown patch and dollar spot on creeping bentgrass and annual bluegrass turf using visible and near infrared spectroscopy. Int. Turf Res. J. 9:705-709.

44. Saeed, I. A. M., MacGuidwin, A. E., Rouse, D. I., and Sharkey, T. D. 1999. Limitation to photosynthesis in Pratylenchus penetrans- and Verticillium dahliae-infected potato. Crop Sci.
39:1340-1346.

45. SAS Institute. 1999. SAS/STAT User's Guide, Version 8, Volumes 1, 2, and 3. SAS Institute Inc. Cary, NC.

46. Settle, D. M., Fry, J. D., and Tisserat, N. A 2001. Dollar spot and brown patch fungicide management strategies in four creeping bentgrass cultivars. Crop Sci. 41:1190-1197.

47. Settle, D. M., Fry, J. D., Todd, T. C., and Tisserat, N. A. 2006. Population dynamics of the lance nematode (Hoplolaimus galeatus) in creeping bentgrass. Plant Dis. 90:44-50.

48. Settle, D. M., Todd, T. C., Fry, J. D., and Tisserat, N. A. 2005. Influence of soil temperature on host suitability of eight turfgrass species to the lance nematode (Hoplolaimus galeatus). Int. Turfgrass Soc. Res. J. 10:265-272.

49. Smiley, R. W., Dernoeden, P. H., and Clarke, B. B. 2005. Pages 117-122 in: Compendium of Turfgrass Diseases, 3rd ed. American Phytopathological Society Press, St. Paul, MN.

50. Steddom, K., Bredehoeft, M. W., Khan, M. and Rush, C. M. 2005. Comparison of visual and multispectral radiometric disease evaluations of Cercospora leaf spot of sugar beet Plant Dis. 89:153-158.

51. Taylor, D. P., Britton, M. P., and Hechler, H. C. 1963. Occurrence of plant parasitic nematodes in Illinois golf greens. Plant Dis. Rep. 47:134135.

52. Todd, T. C., and Tisserat, N. A. 1990. Occurrence, spatial distribution, and pathogenicity of some phytoparasitic nematodes on creeping bentgrass putting greens in Kansas. Plant Dis. 74:660-663.

53. Trenholm, L. E., Schlossberg, M. J., Lee, G., and Parks, W. 2000. An evaluation of multispectral responses on selected turfgrass species. Int. J. Remote Sens. 21:709-721.

54. Walker, N. W., Doad, C. L., Zhang, H., and Martin, D. L. 2002. Factors associated with populations of plant-parasitic nematodes in bentgrass putting greens in Oklahoma. Plant Dis. 86:764-768.

55. Walker, N. W., and Martin, D. L. 2001. Effects of Tylenchorhynchus claytoni on creeping bentgrass. (Abstr.) Phytopathology 91:S93.

56. Watschke, T. L., Dernoeden, P. H., and Shetlar, D. J. 1995. Pages 146-150 in: Managing Turfgrass Pests. Lewis Publishers, Boca Raton, FL.

57. West, J. S., Bravo, C., Oberti, R., Lemaire, D., Moshou, D., and McCartney, H. A. 2003. The potential of optical canopy measurement for targeted control of field crop diseases. Annu. Rev. Phytopathol. 41:593-614.

58. Xu, Q., and Huang, B. 2000. Growth and physiological responses of creeping bentgrass to changes in air and soil temperatures. Crop Sci. 40:1363-1368.

59. Xu Q., and Huang, B. 2000. Effects of differential air and soil temperature on carbohydrate metabolism in creeping bentgrass. Crop Sci. 40:1368-1374.

60. Xu, Q., and Huang, B. 2001. Lowering soil temperatures improves creeping bentgrass growth under heat stress. Crop Sci. 41:18781883

61. Zhang, M., Liu, X., and O'Neill, M. 2002. Spectral discrimination of Phytophthora infestans infection on tomatoes based on principle component and cluster analysis. Int. J. Remote Sens. 23:1095-1107. 